\title{
Genetic Studies on the Pacific Abalone-I \\ Inbreeding and Overdominance as Evidenced by Biochemical \\ Polymorphism in a Wild Population*1
}

Kazuo FujINo*2

(Received September 29, 1977)

\begin{abstract}
With the objectives of genetic improvement of the Pacific abalone, Haliotis discus hannai, a series of genetic studies was initiated. Myogen of shell muscle and esterases of digestive diverticula were studied by starch-gel electrophoresis. The results indicated monomorphism in the former and polymorphisms in four loci of the latter. In each of the F and M loci (genetically independent of each other) of the esterases, three codominant alleles that determine six possible phenotypes were postulated.

Phenotypic incidences of samples taken from a wild population from Iwate Prefecture were analyzed on the basis of S. Wright's and Hardy-Weinberg's Laws of Equilibrium. The homozygote excess in esterase $F$ locus suggested an inbreeding structure in the wild population and led to an estimation of the inbreeding coefficient. An overdominance of heterozygotes in esterase $M$ locus and its association with age groups were observed. On the basis of the ratios between the observed incidences of phenotypes and the expected figures, corrected by the inbreeding coefficient, fitness values were calculated for zygotes of $\mathrm{M}$ locus.
\end{abstract}

FUJiNo et al. ${ }^{1,21}$ described biochemical polymorphism in the Pacific oyster, Crassostrea gigas, for the use as genetic marker in identifying wild and cultured populations as well as in selective breeding. With the same objectives, studied were isozyme variations in myogen and esterases in the Pacific abalone, Haliotis discus hannai. Evidence suggesting inbreeding structure in a wild population and overdominance in some isozyme zygotes is presented.

\section{Materials and Methods}

\section{Materials}

Some two hundred and sixty specimens of the Pacific abalone, $H$. discus hannai, were sampled from waters around the Okkirai Penninsula, Iwate Prefecture. Tissues of shell muscle and digestive diverticula were sampled from each animal for analysis.

\section{Methods}

Preparation of tissue homogenates and electrophoresis were performed by following Fumno et al. ${ }^{11}$ Inbreeding coefficient was estimated by following METTLER et al. ${ }^{31}$ Overdominance was analyzed by comparing observed frequencies of occurrence of phenotypes with their expectations under the Law of Hardy-Weinberg's equilibrium.
Fitness of zygotes was calculated by following FUJINo et al."

\section{Results}

\section{Biochemical Polymorphism}

Anodically migrating six bands were observed in zymogram of myogen from shell muscle, indicating no individual variation among the specimens examined (Fig. 1). Esterase activities were

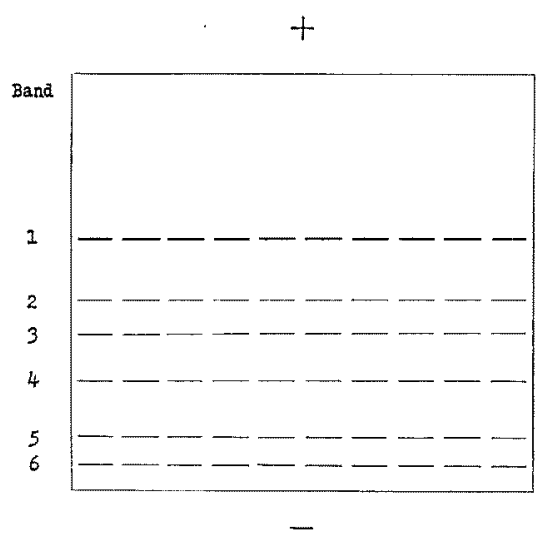

Fig. 1. Diagrammatic representation of zymogram of myogen from shell muscle in the Pacific abalone, $H$. discus hannai.

*1 Supported in part by the Grant from the Ministry of Education, the Government of Japan.

*2 Kitasato University School of Fisheries Sciences, Sanriku, Iwate Prefecture 022-01 (藤野和男: 北里大 学水雇学部). 
observed in anodically migrating four zones, named $F, M, S_{1}$, and $S_{2}$ in zymogram of digestive diverticula. No esterase activity was seen in the cathodic direction. Individual variations were seen in all the four zones, indicating excellent reproducibility in $F$ and $M$ zones but poor in $S_{1}$ and $S_{2}$. Three clear bands, numbered 1, 2, and 3, were seen in $F$ zone, suggesting six phenotypes theoretically possible. Another set of clear three bands, numbered 1,2 , and 3 were seen in $M$ zone, indicating six phenotypes similar to those in $\mathrm{F}$ zone (Fig. 2). Frequencies of occurrence of phenotypes in $\mathbf{F}$ and $\mathbf{M}$ zones are summarized in Tables 1 and 2 respectively. Results of HardyWeinberg analyses for the figures suggested that the variations in each zone were determined by a set of three codominant autosomal alleles. Statistical test for contingency table suggested that the variations in $F$ and $M$ zones were determined by two separate loci independent of each other.

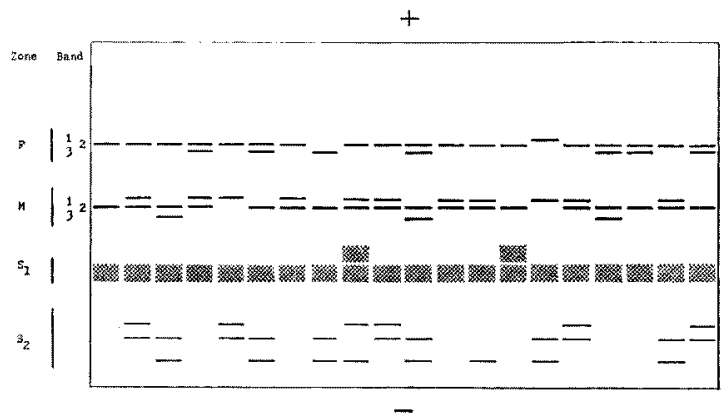

Fig. 2. Diagrammatic representation of variants in esterases from digestive diverticula in the Pacific abalone, $H$. discus hannai.

Table 1. Phenotype and allele frequencies of esterase F-zone variants in the Pacific abalone

\begin{tabular}{|c|c|c|c|c|c|c|c|c|c|c|c|c|c|}
\hline \multirow{2}{*}{\multicolumn{2}{|c|}{$\begin{array}{c}\text { Lot } \\
\text { number }\end{array}$}} & \multicolumn{7}{|c|}{ Phenotypes } & \multicolumn{2}{|c|}{ O/E ratio } & \multicolumn{3}{|c|}{ Alleles } \\
\hline & & \multirow{2}{*}{$\frac{1}{1}$} & \multirow{2}{*}{$\frac{1 \cdot 2}{0}$} & \multirow{2}{*}{$\frac{2}{12}$} & \multirow{2}{*}{$\frac{2 \cdot 3}{6}$} & \multirow{2}{*}{$\frac{3}{1}$} & \multirow{2}{*}{$\frac{1 \cdot 3}{0}$} & \multirow{2}{*}{$\frac{\text { Total }}{20}$} & \multirow{2}{*}{$\frac{2}{1.07}$} & \multirow{2}{*}{$\frac{3}{1.25}$} & \multirow{2}{*}{$\frac{E_{f}^{1}}{0.050}$} & \multirow{2}{*}{$\frac{E_{f}^{2}}{0.750}$} & \multirow{2}{*}{$\frac{E_{z}^{8}}{0.200}$} \\
\hline 1 & 0 & & & & & & & & & & & & \\
\hline & $\mathbf{E}$ & 0.1 & 1.5 & 11.2 & 6.0 & 0.8 & 0.4 & & & & & & \\
\hline \multirow[t]{2}{*}{2} & 0 & 0 & 0 & 17 & 3 & 0 & 0 & 20 & 0.99 & 0.00 & 0.000 & 0.925 & 0.075 \\
\hline & $\mathbf{E}$ & 0.0 & 0.0 & 17.1 & 2.8 & 0.1 & 0.0 & & & & & & \\
\hline \multirow[t]{2}{*}{3} & 0 & 1 & 1 & 15 & 2 & 2 & 0 & 21 & 1.15 & 5.00 & 0.071 & 0.786 & 0.143 \\
\hline & $\mathbf{E}$ & 0.1 & 2.4 & 13.0 & 4.7 & 0.4 & 0.4 & & & & & & \\
\hline \multirow[t]{2}{*}{4} & 0 & 0 & 0 & 17 & 3 & 0 & 0 & 20 & 0.99 & 0.00 & 0.000 & 0.925 & 0.075 \\
\hline & $\mathbf{E}$ & 0.0 & 0.0 & 17.1 & 2.8 & 0.1 & 0.0 & & & & & & \\
\hline \multirow[t]{2}{*}{5} & 0 & 0 & 0 & 24 & 1 & 0 & 0 & 25 & 1.00 & - & 0.000 & 0.980 & 0.020 \\
\hline & $\mathbf{E}$ & 0.0 & 0.0 & 24.0 & 1.0 & 0.0 & 0.0 & & & & & & \\
\hline \multirow[t]{2}{*}{6} & $\mathrm{O}$ & 0 & 1 & 16 & 1 & 2 & 0 & 20 & 1.11 & 6.67 & 0.025 & 0.850 & 0.125 \\
\hline & $\mathbf{E}$ & 0.0 & 0.9 & 14.4 & 4.3 & 0.3 & 0.1 & & & & & & \\
\hline \multirow[t]{2}{*}{7} & $\mathrm{O}$ & 0 & 0 & 16 & 2 & 2 & 0 & 20 & 1.10 & 4.00 & 0.000 & 0.850 & 0.150 \\
\hline & $\mathrm{E}$ & 0.0 & 0.0 & 14.5 & 5.0 & 0.5 & 0.0 & & & & & & \\
\hline \multirow[t]{2}{*}{8} & $\mathrm{O}$ & 0 & 1 & 17 & 3 & 0 & 0 & 21 & 0.99 & 0.00 & 0.024 & 0.905 & 0.071 \\
\hline & $\mathrm{E}$ & 0.0 & 0.9 & 17.2 & 2.7 & 0.1 & 0.1 & & & & & & \\
\hline \multirow[t]{2}{*}{9} & 0 & 0 & 0 & 17 & 1 & 2 & 0 & 20 & 1.11 & 6.67 & 0.000 & 0.875 & 0.125 \\
\hline & $\mathbf{E}$ & 0.0 & 0.0 & 15.3 & 4.4 & 0.3 & 0.0 & & & & & & \\
\hline \multirow[t]{2}{*}{10} & 0 & 1 & 0 & 27 & 3 & 1 & 0 & 32 & 1.06 & 5.00 & 0.031 & 0.891 & 0.078 \\
\hline & $\mathrm{E}$ & 0.0 & 1.8 & 25.4 & 4.4 & 0.2 & 0.2 & & & & & & \\
\hline \multirow[t]{2}{*}{11} & 0 & 0 & 0 & 16 & 2 & 1 & 1 & 20 & 1.10 & 3.33 & 0.025 & 0.850 & 0.125 \\
\hline & E & 0.0 & 0.9 & 14.5 & 4.2 & 0.3 & 0.1 & & & & & & \\
\hline \multirow[t]{2}{*}{12} & $\mathrm{O}$ & 0 & 0 & 17 & 2 & 1 & 0 & 20 & 1.05 & 5.00 & 0.000 & 0.900 & 0.100 \\
\hline & $\mathbf{E}$ & 0.0 & 0.0 & 16.2 & 3.6 & 0.2 & 0.0 & & & & & & \\
\hline \multirow[t]{2}{*}{ Total } & 0 & 3 & 3 & 211 & 29 & 12 & 1 & 259 & 1.06 & 4.29 & 0.019 & 0.877 & 0.104 \\
\hline & $\mathbf{E}$ & 0.1 & 8.6 & 199.3 & 47.2 & 2.8 & 1.0 & & & & & & \\
\hline
\end{tabular}


Table 2. Phenotype and allele frequencies of esterase M-zone variants in the Pacific abalone

\begin{tabular}{|c|c|c|c|c|c|c|c|c|c|c|c|c|c|}
\hline \multirow{2}{*}{\multicolumn{2}{|c|}{$\begin{array}{c}\text { Lot } \\
\text { number }\end{array}$}} & \multicolumn{7}{|c|}{ Phenotypes } & \multicolumn{2}{|c|}{$\mathrm{O} / \mathrm{E}$ ratio } & \multicolumn{3}{|c|}{ Alleles } \\
\hline & & \multirow{2}{*}{$\frac{1}{2}$} & \multirow{2}{*}{$\frac{1 \cdot 2}{9}$} & \multirow{2}{*}{$\frac{2}{6}$} & \multirow{2}{*}{$\begin{array}{l}2 \cdot 3 \\
3\end{array}$} & \multirow{2}{*}{$\frac{3}{0}$} & \multirow{2}{*}{$\frac{1 \cdot 3}{0}$} & \multirow{2}{*}{$\frac{\text { Total }}{20}$} & \multirow{2}{*}{$\frac{1 \cdot 2}{1.15}$} & \multirow{2}{*}{$\frac{2 \cdot 3}{1.67}$} & \multirow{2}{*}{$\frac{\mathrm{E}_{\mathrm{m}}{ }^{1}}{0.325}$} & \multirow{2}{*}{$\frac{\mathrm{E}_{\mathrm{m}}{ }^{2}}{0.600}$} & \multirow{2}{*}{$\frac{\mathrm{E}_{\mathrm{m}}{ }^{\mathrm{s}}}{0.075}$} \\
\hline 1 & 0 & & & & & & & & & & & & \\
\hline & $\mathrm{E}$ & 2.1 & 7.8 & 7.2 & 1.8 & 0.1 & 1.0 & & & & & & \\
\hline \multirow[t]{2}{*}{2} & $\mathbf{O}$ & 0 & 7 & 3 & 7 & 2 & 1 & 20 & 1.75 & 1.17 & 0.200 & 0.500 & 0.300 \\
\hline & $\mathrm{E}$ & 0.8 & 4.0 & 5.0 & 6.0 & 1.8 & 2.4 & & & & & & \\
\hline \multirow[t]{2}{*}{3} & $\mathrm{O}$ & 1 & 4 & 8 & 8 & 0 & 0 & 21 & 1.00 & 1.51 & 0.143 & 0.667 & 0.190 \\
\hline & $\mathrm{E}$ & 0.4 & 4.0 & 9.4 & 5.3 & 0.8 & 1.1 & & & & & & \\
\hline \multirow[t]{2}{*}{4} & 0 & 1 & 6 & 9 & 4 & 0 & 0 & 20 & 1.07 & 1.43 & 0.200 & 0.700 & 0.100 \\
\hline & $\mathbf{E}$ & 0.8 & 5.6 & 9.8 & 2.8 & 0.2 & 0.8 & & & & & & \\
\hline \multirow[t]{2}{*}{5} & $\mathrm{O}$ & 2 & 3 & 10 & 9 & 1 & 0 & 25 & 0.67 & 1.29 & 0.140 & 0.640 & 0.220 \\
\hline & $\mathrm{E}$ & 0.5 & 4.5 & 10.3 & 7.0 & 1.2 & 1.5 & & & & & & \\
\hline \multirow[t]{2}{*}{6} & 0 & 1 & 6 & 7 & 4 & 2 & 0 & 20 & 1.25 & 0.83 & 0.200 & 0.600 & 0.200 \\
\hline & $\mathrm{E}$ & 0.8 & 4.8 & 7.2 & 4.8 & 0.8 & 1.6 & & & & & & \\
\hline \multirow[t]{2}{*}{7} & $\mathrm{O}$ & 1 & 8 & 5 & 3 & 3 & 0 & 20 & 1.51 & 0.64 & 0.250 & 0.525 & 0.225 \\
\hline & $E$ & 1.3 & 5.3 & 5.4 & 4.7 & 1.0 & 2.3 & & & & & & \\
\hline \multirow[t]{2}{*}{8} & 0 & 0 & 7 & 8 & 4 & 2 & 0 & 21 & 1.56 & 0.78 & 0.167 & 0.643 & 0.190 \\
\hline & $\mathbf{E}$ & 0.6 & 4.5 & 8.7 & 5.1 & 0.8 & 1.3 & & & & & & \\
\hline \multirow[t]{2}{*}{9} & 0 & 2 & 7 & 6 & 3 & 2 & 0 & 20 & 1.17 & 0.77 & 0.275 & 0.550 & 0.175 \\
\hline & E & 1.5 & 6.0 & 6.1 & 3.9 & 0.6 & 1.9 & & & & & & \\
\hline \multirow[t]{2}{*}{10} & 0 & 6 & 14 & 7 & 5 & 0 & 0 & 32 & 1.04 & 1.92 & 0.406 & 0.516 & 0.078 \\
\hline & $\mathrm{E}$ & 5.3 & 13.4 & 8.5 & 2.6 & 0.2 & 2.0 & & & & & & \\
\hline \multirow[t]{2}{*}{11} & 0 & 3 & 6 & 8 & 1 & 2 & 0 & 20 & 0.87 & 0.34 & 0.300 & 0.575 & 0.125 \\
\hline & $\mathrm{E}$ & 1.8 & 6.9 & 6.6 & 2.9 & 0.3 & 1.5 & & & & & & \\
\hline \multirow[t]{2}{*}{12} & 0 & 5 & 8 & 5 & 2 & 0 & 0 & 20 & 0.89 & 2.00 & 0.450 & 0.500 & 0.050 \\
\hline & $\mathbf{E}$ & 4.0 & 9.0 & 5.0 & 1.0 & 0.1 & 0.9 & & & & & & \\
\hline \multirow[t]{2}{*}{ Total } & 0 & 24 & 85 & 82 & 53 & 14 & 1 & 259 & 1.09 & 1.11 & 0.259 & 0.583 & 0.158 \\
\hline & $\mathrm{E}$ & 17.4 & 78.2 & 88.0 & 47.7 & 6.5 & 21.2 & & & & & & \\
\hline
\end{tabular}

\section{Inbreeding and Overdominance}

More careful comparisons between observed and expected incidences of phenotypes disclosed deficiency in occurrence of heterozygotes in $F$ zone and excessive occurrence of heterozygotes in $M$ zone as shown in the total numbers of the 12 lots in Tables 1 and 2. Deficiency in heterozygote frequency in $\mathrm{F}$ zone reflected on excessive occurrence of homozygotes as indicated by $\mathrm{O} / \mathrm{E}$ ratios for the phenotypes 2 and 3 in Table 1. Because of low frequency, the value for the phenotype 1 is not shown. Excess of homozygotes in $F$ zone was seen consistently in different shell length groups (Table 3). The evidence suggests existence of inbreeding structure in the Pacific abalone population according to METTLER et al. ${ }^{31}$ They summarized genotypic frequencies in a randommating population with no inbreeding and partial inbreeding for a two codominant allelic system by using inbreeding coefficient $(F)$ as follows.

Table 3. $\mathrm{O} / \mathrm{E}$ ratios of phenotypic incidences of esterase $\mathrm{F}$ system in different shell-length groups of the Pacific abalone

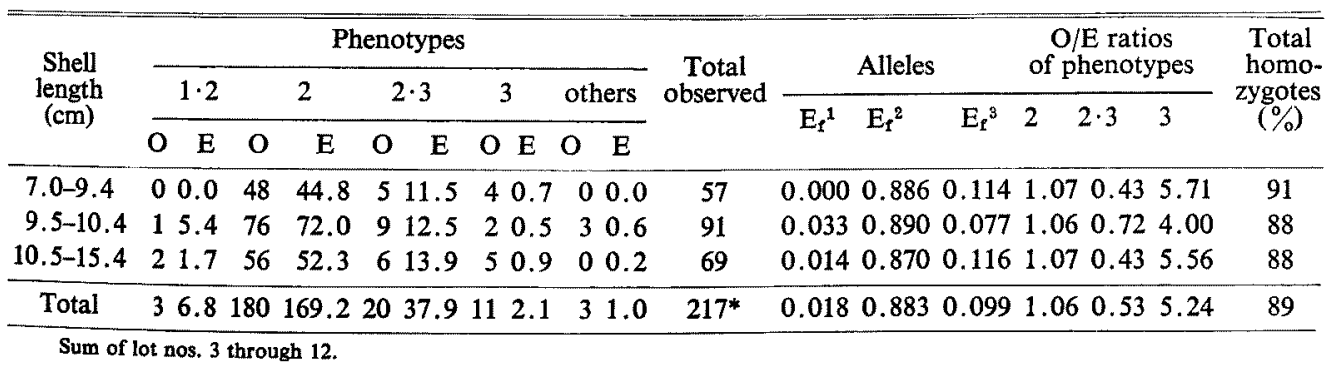




\begin{tabular}{lcccc}
\hline \multirow{2}{*}{$\begin{array}{c}\text { Generations Inbreeding } \\
\text { of inbreeding coefficient }\end{array}$} & \multicolumn{4}{c}{ Genotype frequencies } \\
\cline { 2 - 5 } & & $A / A$ & $A / a$ & $a / a$ \\
\hline $\begin{array}{c}\text { None (Hardy- } \\
\text { Weinberg's }\end{array}$ & $F=0$ & $P^{2}$ & $2 p q$ & $q^{2}$ \\
$\begin{array}{c}\text { equilibrium) } \\
\text { One or more } \\
\text { (Wright's } \\
\begin{array}{c}\text { equilibrium) } \\
\text { Infinite }\end{array}\end{array}$ & $F>F>0$ & $P^{2}+F p q$ & $2 p q$ & $q^{2}+F p q$ \\
\hline & & & $-2 F p q$ & \\
& & $P^{2}+p q$ & 0 & $q^{2}+p q$ \\
\hline
\end{tabular}

According to the above relationships, $F$ can be calculated through the following equation from $\mathrm{O} / \mathrm{E}$ ratio for the heterozygote $(A / a)$.

or

$$
\begin{gathered}
\frac{2 p q-2 F p q}{2 p q}=1-F=\mathrm{O} / \mathrm{E}(A / a), \\
F=1-\mathrm{O} / \mathrm{E}(A / a),
\end{gathered}
$$

where $\mathrm{O}$ and $\mathrm{E}$ are number of the heterozygote $(A / a)$ observed and expected respectively under Hardy-Weinbergs equilibrium. Being applied for a three codominant allelic system like esterase $\mathbf{F}$ zone in the Pacific abalone,

$$
F=1-\frac{\text { total number of three heterozygotes observed }}{\text { total number of three heterozygotes expected }}
$$

From Table 1,

$$
F=1-\frac{3+29+1}{8.6+47.2+1.0}=0.42 .
$$

Overdominance is evident in heterozygotes 1.2 and 2.3 in $M$ locus as noted already (Table 2). Figures of $\mathrm{O} / \mathrm{E}$ ratio for the heterozygotes, however, vary from one lot to the others quite markedly, ranging from those greater than the unit to far below the unit. The wide range variations in $\mathrm{O} / \mathrm{E}$ ratio can be explained by another observation on the association between $\mathrm{O} / \mathrm{E}$ ratio and shell length as shown in Table 4. It can be seen from this table that $\mathrm{O} / \mathrm{E}$ ratio for heterozygote 1.2 decreases and that for 2.3 increases with the increment of shell length of animals. The associa- tion of $\mathrm{O} / \mathrm{E}$ value to size of animals in the former seems similar in nature to that observed in serum transferrin locus in skipjack tuna population"

Inbreeding structure evidenced by homozygote excess in $F$ locus should also reflect on proportional occurrences of zygotes in $M$ locus. In order to estimate fitness values for zygotes in $M$ locus, expected frequencies of zygotes $(E)$ in $M$ locus were corrected on the basis of the relations of Wright's equilibrium cited in the foregoing paragraph by using inbreeding coefficient $F=0.42$ obtained before. Fitness value for phenotypes $1 \cdot 2,2,2 \cdot 3$, and others were calculated through the corrected $\mathrm{O} / \mathrm{E}$ ratios according to FujINo et $a l .{ }^{4}$ for different shell length groups (Table 5).

Table 5. Fitness of phenotypes of esterase $M$ system in the Pacific abalone

\begin{tabular}{ccccc}
\hline $\begin{array}{c}\text { Shell } \\
\text { length } \\
(\mathrm{cm})\end{array}$ & $1 \cdot 2$ & 2 & $2 \cdot 3$ & others \\
\cline { 2 - 5 } & 1 & 0.36 & 0.50 & 0.29 \\
$7.0-9.4$ & 0.87 & 0.36 & 1 & 0.27 \\
$9.5-10.4$ & 0.64 & 0.33 & 1 & 0.27 \\
$10.5-15.4$ & 0.64 & 0.32 \\
\hline Total & 0.96 & 0.41 & 1 & 0.30 . \\
\hline
\end{tabular}

It can be seen from this table that the highest fitness value appear in zygote 1.2 in the smallest group of animals (shell length range 7.0 to $9.4 \mathrm{~cm}$ ) but in zygote 2.3 in larger groups. The observations suggest marked differences in survival rates between zygotes 1.2 and 2.3 according to growth of animals. Despite such differential survival rates, gene frequencies could be maintained from one generation to the next in a population as discussed earlier" ${ }^{4}$.

\section{Discussions}

Inbreeding Structure and Population Biology

\begin{tabular}{|c|c|c|c|c|c|c|c|c|c|c|c|c|c|c|}
\hline \multirow{3}{*}{$\begin{array}{l}\text { Shell } \\
\text { length } \\
\text { (cm) }\end{array}$} & \multicolumn{8}{|c|}{ Phenotypes } & \multirow{3}{*}{$\begin{array}{c}\text { Total } \\
\text { observed }\end{array}$} & \multirow{2}{*}{\multicolumn{3}{|c|}{ Alleles }} & \multirow{2}{*}{\multicolumn{2}{|c|}{$\begin{array}{l}\mathrm{O} / \mathrm{E} \text { ratios } \\
\text { of phenotypes }\end{array}$}} \\
\hline & \multicolumn{2}{|c|}{$1 \cdot 2$} & \multicolumn{2}{|r|}{2} & \multicolumn{2}{|c|}{$2 \cdot 3$} & \multicolumn{2}{|c|}{ others } & & & & & & \\
\hline & $\mathrm{O}$ & $\mathrm{E}$ & 0 & $\mathbf{E}$ & 0 & $\mathbf{E}$ & 0 & $\mathrm{E}$ & & $\mathrm{E}_{\mathrm{m}}^{1}$ & $\mathrm{E}_{\mathrm{m}}^{2}$ & $E_{m}{ }^{8}$ & $1 \cdot 2$ & $2 \cdot 3$ \\
\hline $7.0-9.4$ & 22 & 17.3 & 19 & 19.4 & 7 & 10.9 & 10 & 10.4 & 58 & 0.259 & 0.578 & 0.163 & 1.27 & 0.64 \\
\hline $9.5-10.4$ & 27 & 26.0 & 31 & 33.3 & 21 & 17.5 & 12 & 14.2 & 91 & 0.236 & 0.605 & 0.159 & 1.04 & 1.20 \\
\hline $10.5-15.4$ & 20 & 23.0 & 22 & 22.5 & 14 & 10.3 & 12 & 12.2 & 68 & 0.294 & 0.574 & 0.132 & 0.87 & 1.36 \\
\hline Total & 69 & 66.3 & 72 & 75.0 & 42 & 38.8 & 34 & 36.9 & $217^{*}$ & 0.260 & 0.588 & 0.152 & 1.04 & 1.08 \\
\hline
\end{tabular}

Inbreeding structure as evidenced by esterase

Table 4. O/E ratios of phenotypic incidences of esterase $M$ system in different shell-length groups of the Pacific abalone

* Sum of lot nos. 3 through 12. 
F locus is now supported by more recent observations on another isozyme locus (FuJINo: unpublished data). The results of such observations may stimulate one's interest to initiate a variety of ecological and behavioral studies on populations of the Pacific abalone and the other species of mobile shellfish. Some observation indicates that mature animals of the Pacific abalone move from deep waters to shallow areas to mate during a breeding season ${ }^{51}$. The observation together with the evidence of inbreeding strongly suggest that the animals have some mechanisms of identifying each other to maintain group of animals in which they mate in random with partial inbreeding. Total percentage homozygotes in esterase $F$ locus $(87 \%$ from Table 1) suggest that degree of inbreeding in the Pacific abalone seems close to that with systematic mating among double first cousins ${ }^{3}$.

\section{Fitness and Selective Breeding}

Overdominance of heterozygotes observed in esterase $M$ locus needs to be examined by experimental selective breeding under different genetic and environmental backgrounds. Accurate quantitative relationships must be estimated between age and fitness values of zygotes through further accumulation of the data for wider ranges of age groups of animals before practical applications in animal breeding. Consistent pro- duction of seed animals with superior quality and performance is essential in aquaculture industry. Utilization of overdominance of zygotes could be one of a variety of promising ways of genetic improvements in immediate future.

\section{Acknowledgements}

Dr. Kan-ichi SAKaI, the Member of the Science Council of Japan gave me continued encouraging supports to conduct a series of genetic studies on aquatic populations. Careful technical assistances of Messrs Kan Morishita and Takayoshi Numata and Miss Reiko AMANo are greatly appreciated.

\section{References}

1) K. Fujino and N. NagaYA: Bull. Japan. Soc. Sci. Fish., 43, 983-988 (1977).

2) K. Fumno and N. Nagaya: Bull. Japan. Soc. Sci. Fish., 43, 1455-1459 (1977).

3) L. E. MetTler and T. G. GreGG: Population Genetics and Evolution, Prentice-Hall, Inc., Englewood Cliffs, New Jersey, 1969, p. 212.

4) K. Fujino and T. Kang: Genetics, 59, 79-91 (1968)

5) T. INo: Biological Studies on the Propagation of Japanese Abalone (Genus Halıotrs), Tokai Shobo, Tokyo, 1953, p. 108. (in Japanese). 